\title{
Thomas Aquinas's Metaphysical Discourses on When Human Life Begins
}

\author{
Nico P. Swartz ${ }^{1} \&$ Obonye Jonas ${ }^{1}$ \\ ${ }^{1}$ Department of Law, Faculty of Social Sciences, University of Botswana, Botswana \\ Correspondence: Nico P. Swartz, Department of Law, Faculty of Social Sciences, University of Botswana, Private \\ Bag 00705, Gaborone, Botswana. Tel: 267-355-2373. E-mail: nico.swartz@mopipi.ub.bw
}

Received: September 5, 2012 Accepted: October 15, 2012 Online Published: November 26, 2012

doi: $10.5539 /$ res.v4n5p 157

URL: http://dx.doi.org/10.5539/res.v4n5p157

\begin{abstract}
Many people believe that abortion takes a human life and is therefore tantamount to murder. If human life begins at conception, then abortion always involves the taking of human life. Thomas Aquinas, therefore, denies that human life begins at conception. Until the fetus has a human soul - it is not a human being. Thus, to destroy a fetus is not to destroy a human being. Aquinas believes the fetus will go out of existence regardless of whether it is aborted. He alludes that you and I could not have been aborted in the first trimester, because you and I did not exist then. Aquinas believes it is around mid-gestation that a fetus begins to engage in cognitive activity. It is the stadium where the brain has sufficiently develops to support the operations of intellect. If we understand a person to be an individual who possess a degree of self-consciousness, then, the fetus does not qualify to be called a person. This notion has been adopted by the South African Choice of Termination of Pregnancy Act (Act 92 of 1996), wherein someone's right to privacy or autonomy can in some cases outweigh the value of a human life.
\end{abstract}

Keywords: fetus, life, abortion, soul, church

\section{Research Question and Methodology}

The research question or purpose for this study embarks upon the question when human life begins. This paper aims to solve this question by employing the metaphysical discourses of the division of the embryo as having a nutritive, then a sensory and finally a rational soul. Thomas Aquinas means that it is only in the last stage, the rational category, that the intellect needs a body. Until that capacity is present, the rational soul cannot be infused. It is only then that we have a human life. This conception can be construe in a Thomistic sense, that to destroy an embryo is not to destroy a human being or human life.

In order to satisfactorily addressing the research question, it is important to note that this paper opted for a theoretical approach. The data, obtained from primary (original works in Latin by Thomas Aquinas and other ancient authors) and secondary resources (other writer's renditions, comments or annotations on the works of Thomas Aquinas), are complemented by analysis proffered by the author.

\section{Introduction}

It was accepted that each human person was once a fetus and that a healthy human fetus will become an adult human person, such as you and I (Note 1). This observation poses trouble for the metaphysical approach of Thomas Aquinas.

Although religion (and the law) do not possess definitive answers to ethical dilemmas, it consists of many rich traditions that have grappled with the meaning of life and as such it has something valuable to offer the contemporary discussion (Note 2).

The Christian religion has been largely responsible for influencing the West toward a high valuation of individual life generally and of newborn life in particular (Note 3).

Knowledge of the religious and philosophical influences in our backgrounds can help us describe how we came to our present convictions, attitudes and actions (Note 4).

Thomas Aquinas wants to be part of the solutions to the ethical dilemmas we face regarding the status of a human fetus. 


\section{Thomas Aquinas's Position with Regard to Abortion vis-à-vis the Catholic Church}

It is unfortunate to conflate interest in Medieval philosophy, especially in the work of Thomas Aquinas, with the Roman Catholic Church's stand on abortion. Abortion has become part of the defining character of Catholicism.

Officially, the Church has never taken a position on the philosophical question of when human life begins. In a recent encyclical, John Paul II notes that the Church has not "expressly committed itself" on the moment when human life begins (Note 5). But the Church's rhetoric leaves little room for doubt. In that same encyclical, the Pope writes that abortion "destroys the life of a human being" and "directly violates the divine commandment 'You shall not kill'" (Note 6). That seems fairly express.

The pivotal moment came in 1869, when Pope Pius IX eliminated the Church's long-held distinction between an animated and an unanimated fetus and ruled that all abortions were subject to excommunication (Note 7).

Thomas Aquinas tends here to show what is wrong with the Church's position concerning abortion (Note 8).

\section{Internal Nature of Human Beings: Form/Matter Postulates}

In describing the generation of natural substances, Thomas Aquinas takes himself to be choosing Aristotle's biology over Plato's metaphysics (Note 9). Aquinas follows Aristotle in appealing to internal principles as an explanation of natural generation. He embraces the idea that in every case where a substance is generated, there must be some material from which the new substance is generated. There must be a form that the substance takes on and there must be an agent to make the transformation occur. Aquinas cites Aristotle: "If there are forms species beyond the singulars, they are of no use in the generation and substance of things" (Note 10).

Aquinas stresses that forms are never generated. He says: "Forms are not made, but are brought out from the potential of the matter" (Note 11). Generation consists in the production neither of the matter nor of the form, but of the matter-form composite ... only the composite is generated" (Note 12).

Aquinas exerts that forms are brought out from matter and thus highlights his resistance to dualistic forms of hylomorphism. He holds that the production of a sensory soul is nothing other than to convert matter from potentiality to actuality (Note 13). Aquinas believes that forms exist potentially in matter (Note 14). This deduction will eventually form the basis of his thoughts regarding his views about fetal life.

\section{The Role of the Sun in Generation}

In following the science of his day, Aquinas believes that both plants and lower animals can be generated out of decaying matter through the sun's power. Some animals can be generated without any sort of virtus formativa. He upholds, "In animals generated from rotting, the power of the heavens takes the place of the formative power in the semen" (Note 15).

Aquinas states that the sun brings out new forms in rotting matter simply in virtue of producing the right sorts of changes in the right kind of matter. He believes, this cannot happen in higher animals (such as human beings), because of their complexity. He alleges that human kind require the power of semen along with the power of the heavens (Note 16).

\section{The Role of Parents}

Aquinas believes that the mother supplies the material, and that the father is the agent, inasmuch as his semen is what causes the material supplied by the mother to take on the form of an embryo (Note 17). The semen contains a virtus formativa, which is what directs the embryo's development toward the appropriate form, its soul. Just as DNA provides a complete blueprint for the body's development, the virtus formativa contains every feature of the developing body, but contains it "virtually" or "potentially" rather than actually (Note 18). This formative power is not itself a soul. It is where the semen would be a regarded as a living creature even before conception (Note 19). Instead, the virtus formativa directs the development of the embryo, which goes through a series of forms on the way to its ultimate nature (Note 20).

Although the father is the remote cause of generation, the direct cause is the semen, which acts as a kind of instrument through which the father exercises his indirect agency (Note 21).

Aquinas explains virtual transmission from the parents to the embryo. In doing so, he develops an analogy between the way semen contains the soul and way a builder has in mind the plan of a house: "The active power is in the sperm, although it is not actually the soul, nevertheless is the soul virtually, just as the form of a house in the soul is not the house actually, but virtually. So just as the house's form can be made in matter from the house's form in the mind, so the power of the semen can make a complete soul (except for intellect, which comes from outside) (Note 22). 


\section{Generation Requires Corruption}

Thomas Aquinas differentiates between an actual human and a potential human. On this analysis, he casts it illegitimate to speak of the human body even before the rational soul has been infused. Aquinas warns though, the body's being potentially human does not entail its being actually human (Note 23). When we say that things are potentially such and such, we mean that they are not such and such, but that they could be. Could this be applied to a human embryo? Aquinas asserts that there are many things that are potentially human beings. Each of the cells of a human body is potentially a human being, inasmuch as each one might be developed into a full-fledged human being (Note 24).

But Thomas Aquinas would say that my early life as an embryo, is not really my life, insofar as a I, the human being, did not exist then. He means a different, non-human substance, existed then (Note 25).

Thomas Aquinas infuses changes into the development of the fetus. His thinking is in line with the general view of generation and corruption. He alludes that where some complex substance is generated, its development runs through a series of intermediary substances, each with its own substantial form. He mentions: "It is clear in the generation of composite things, such as animals, that in between the principle of generation (the semen) and the ultimate form of the complete animal, there are many intermediary generations" (Note 26). It can therefore be infers, that the same is true for corruption: "It is not that, once the soul is corrupted, the body of the animal immediately dissolves into its elements: instead, this happens through many intermediary corruptions" (Note 27). Aquinas means if we suppose that the soul is united to body as its form, then it seems entirely impossible for several, different souls to be within one body (Note 28). Only two substantial forms are in interplay with each other: the one that is given up and the one that is taken on (Note 29).

Thomas Aquinas asserts that a change in species entails a change in identity. The prior substance must be corrupted and a new one generated (Note 30). Human generation fits the complex model: "First the seed appears, then the blood, and so on until the form of the human" (Note 31). Aquinas emphasized that the human being begins when the human mind comes into the scene.

On the basis of this metaphysical conception, Thomas Aquinas avers that the embryo first has a nutritive soul, then a sensory soul, and finally a rational soul (Note 32). He rejects the notion that there are multiple souls. He writes, "When the rational soul is infused, the prior soul gives way; this must be the case, Aquinas believes, because in all cases 'one thing has just one substantial form"" (Note 33). He thus rejects the idea of multiple souls, because the prior sensory form is cast off (abiecta) when the rational soul is infused (Note 34). Aquinas shows sympathy with the ordinary reader when he says, "Because an embryo first has a nutritive soul, then a sensory soul, and finally (seemingly on top of all) a rational soul, it looks as if a human being should have three different souls" (Note 35). The sensory soul comes later and the rational soul later still. Each time a new soul develops, a new substance comes into existence. He writes: "The vegetative soul comes first, when the embryo lives the life of a plant. Then it is corrupted, and a more complete soul follows, at once both nutritive and sensory, and then the embryo lives the life of an animal. But once this is corrupted, the rational soul follows, introduced from without" (Note 36). Aquinas concludes by saying that there are no multiple souls (Note 37). He reasserted that the human being has only one soul, a rational soul or a rational soul is a human being's only substantial form (Note 38).

Thomas Aquinas means before the final stage, we have something that is alive, and something that, in virtue of its potential, merits the adjective "human." He reassures us that only at this last stage do we have a human being (Note 39).

Thomas Aquinas says about the sequence of coming into and going out of existence: "There is nothing absurd about an intermediary's being generated and then immediately afterwards being broken off. For these intermediaries do not have a complete species, but are on route toward that species" (Note 40).

Thomas Aquinas ensures us that generation involves constant discontinuity, as is evident in this research. He asserts that the human being that now exists never was an embryo. According to Aquinas, to destroy an embryo is not to destroy a human being, nor is it even to destroy some entity that will become a human being. He argues that the process of generation ensures that the embryo will go out of existence regardless of whether it is aborted. He reiterates: when a new substance comes into existence, the old one goes out of existence: “... the generation of one thing is always the corruption of another" (Note 41). He means the destruction of the embryo is not the destruction of a complete and enduring substance. He alludes that you and I could not have been aborted in the first trimester, because you and I did not exist then. Thomas Aquinas believes what exist then, existed only for a transient moment (Note 42). 
In sum, it is stressed vehemently in this research that generation requires corruption. In human beings, when a more perfect form comes on, the prior is corrupted, in such a way that the following form has whatever the first had, and still more (Note 43). Thomas Aquinas states when a fetus becomes a human being, the thing that did exist (the fetus with a merely sensory soul) is corrupted or rather the fetus goes out of existence in the same way that a caterpillar goes out of existence when it becomes a butterfly (Note 44).

\section{Requirement of a Body}

The intellect needs a body as its instrument. For the human mind to operate at all, it must be attached to the right sort of body. Aquinas says that the intellective soul needed to be united to a body that could serve as an appropriate organ for sensation (Note 45).

Aquinas conceives of the soul as substantial form. A substantial form makes a thing exist as the sort of thing it is. A substantial form gives a thing its very identity, its very existence (Note 46). This notion must be read in conjunction with a human being. A human being must have the capacities for sensation, emotion, desire and memory. According to Aquinas, these capacities require the right sort of body (Note 47). He believes without such a body, God could not infuse the human soul. To be a human requires something further: reasoning or thinking. Anything with a human soul must have the capacity for thought (Note 48). Until that capacity is present, the rational soul cannot be infused.

The question can be asked, if the human soul can exist without an appropriately organized body, then why couldn't human souls exist without any body at all, before the moment of conception. Aquinas argues against the pre-existence of the human soul. According to Aquinas, Origin (185-253) held that human souls pre-existed their bodies and were forced into them as a form of punishment (Note 49). Augustine held a similar view as Origin and says our souls might have existed before their current earthly incarnation. A citation of Augustine to that effect, "I do not know, Lord, where I came here form, into this dying life, as I call it, or living death" (Note 50).

Aquinas's chief argument against the soul's pre-existence rests on the claim that God would not create a human soul except as the form of a human body. In his Questiones Disputatio de Potentia, Aquinas reasons as follows, the human soul is not naturally complete outside the body, and God does not create the human soul outside the body (Note 51).

Before the rational soul is infused, the fetus has no mind with which to conceptualize. Once the rational soul is infused, Aquinas believes, it is only then that the newly human fetus begins to use its mind. The fetus receives enough sensory stimulus to set the intellect in motion (Note 52). It is around mid-gestation of pregnancy that a fetus begins to engage in a cognitive activity. It is the stadium where the brain has sufficiently developed to support the operations of intellect (Note 53).

Whether a fetus is genuinely engaging in conceptual thought is a dubious matter, but Aquinas gives that fetus the benefit of the doubt, pushing the beginnings of human life as far back as he can while remaining consistent with his broader theory of the soul.

\section{When Does Human Life Begin?}

The abortion debate has become the central ethical issue of our time. Many people believe that abortion takes a human life and is therefore tantamount to murder (Note 54).

If human life begins at conception, then abortion always involves the taking of human life. Aquinas therefore denies that human life begins at conception (Note 55).

He's thinking about when life begins is shaped by a view that material beings have life in virtue of having a soul (Note 56). Human beings are regarded as humans by their possession of a human or rational soul. The rational soul must be brought into existence by a non-physical agent, God. Aquinas says, "The soul is created by God, and infused into the human body" (Note 57). The human beings have therefore an immaterial soul created directly by God. This view holds that human life cannot begin at conception. The question that can be posed that buttressed the sentence before, will read, "If the rational soul is therefore not a product of sperm meeting egg, then why should we suppose that it comes into existence at conception? If to be human is to have a God-given soul, then the presence of the human genetic code at conception shows nothing about whether the embryo is a human being. Aquinas stresses therefore - until the fetus has a human soul - it is not a human being" (Note 58).

Thomas Aquinas says human life is infused at that point when the fetus is sufficiently developed, in its brain and sensory systems, to support the soul's intellectual operations.

Thomas Aquinas takes human life to begin at quickening, the point at which the fetus begins to move within the uterus. This comes around the twentieth week of pregnancy. According to Aquinas, the rational soul is not what 
makes such movement possible, the capacity for movement is present in the fetus before the rational soul is infused. There is therefore no reason the fetus could move before the arrival of the rational soul. Quickening might occur well after the rational soul's infusion. Aquinas believes that the fetus becomes human at the moment of quickening (Note 59).

He is of the opinion that it would be pointless for God to infuse the human soul at any earlier point. Aquinas reasserts that it is impossible for the rational soul to be infused at the moment of conception. He says, "It cannot be said that the soul ... is in the semen from the beginning ..." (Note 60).

On the strength of this metaphysical notion, it seems to be absurd to think that a few unformed cells count as a human being (Note 61).

\section{Thomas Aquinas's Notions on When Human Life Begins Buttress by Modern Day Embryologists}

With regard to the former paragraph or what is earlier been said, it seems therefore strange to say that I was once an unthinking embryo. "I" is a personal pronoun and calling something by a personal pronoun implies that it is a person, a rational self-conscious being. The embryo is not an "I," but an "it." So we cannot ask who a fetus is, since that is to ask which person it is, and a fetus is (according to the tenor of this research) not been regarded as a person before the moment of quickening (Note 62).

You begin to exist when you come into being. Embriologists believe it to be about sixteen days after fertilization, when the cells that develop into the fetus become specialized and begin to grow and function in a coordinated manner. Thomas Aquinas accords a longer time frame for existence or coming into being. He mentions mid-gestation or twentieth week of pregnancy (quickening). Embriologists, however, believe that prior to the sixteenth days period: "We do not have a living individual human body, but a mass of pre-programmed loosely organized developing cells and heterogeneous tissues until their 'clock' mechanisms become synchronized and triggered to harmoniously organize, differentiate and grow as heterogeneous parts of a single whole human organism" (Note 63).

It is said that a human embryo does not begin to acquire even the rudiments of a cerebrum until at least six weeks after fertilization. If embryologists are right, you could not now be related to a five-month-old human fetus in any psychological way (Note 64). Thus, I could not have been a human embryo or fetus.

The cerebrum cannot support thought or awareness until its neurons can communicate with one another. This takes place when they get connected together with synapses, roughly twenty-five to thirty-two weeks after fertilization. This time frame seems to be much closer to Thomas Aquinas's. Before this time, there is no capacity for conscious awareness or reasoning. It is said, before synapses are formed, the fetal brain is just a collection of nerve cells. The fetus is therefore incapable of awareness or volition" (Note 65).

The cerebral cortex "comes into existence as a functional entity" between twenty-five to thirty-weeks after fertilization. Continuous EEG patterns are not observed until about thirty weeks. According to Pasnau, Morowitz and Trefil state in their book, The Facts of Life: Science and the Abortion Controversy (1992), that fetuses begin to generate EEG readings around the twenty-fifth week of gestation or even later (Note 66). An embryologist, Clifford Grobstein, writes: "The available facts speak against the presence of an imaginable state of sentience prior to twenty weeks after fertilization and for a period of uncertain duration beyond - in all likelihood to eat least thirty weeks, when cortical maturation and connectivity noticeably rise" (Note 67).

Although different time frames are mentioned, it is evident that a human life begins well after conception. According to Thomas Aquinas, it will be the twentieth week of gestation or pregnancy.

\section{Nothing Is Ever First A Fetus and Later A Person}

The claim that nothing is ever first a fetus and later a person poses or faces serious philosophical problems for Thomas Aquinas's metaphysical discourses.

Ethicists, on the one hand, agree that a human fetus is a potential person. It might later be a person: "It is obviously true that the normal fetus is at least a potential person: it is an entity which will ... develop into something incontestably a person ..." (Note 68). From this angle, it seems that they assume that it is possible for something to be an unthinking fetus at one time and a person later on. Embryologists (in support of Thomas Aquinas) would argue, on the other hand, that a fetus (before mid-gestation or quickening) is not even a potential person (Note 69).

As mentioned earlier in the research is the notion that people is or are distinguish from non-people on grounds of the concepts of rationality and self-consciousness (Note 70). It goes along the line that a fetus does not come to 
be a person. During some vague period, some six or seven months after the fetus was conceived, a thinking being only appears then (Note 71).

After envisaging the tenor of this research, the question one can asks is what happens to the original fetus then? Two possibilities seem to surface, which are concomitant to Thomas Aquinas's generation and corruption doctrine. One is that the fetus ceases to exist and is replaced by a person and the other, is that the fetus continues to exist, but never comes to be a person. These two possibilities has the same effect in Thomas Aquinas's metaphysics: He is simply stating that human life does not begin well after conception (mid-gestation or quickening). According to the first possibility, it is impossible for a human fetus to come to be a normal, adult human being. The fetus ceases to exist as soon as its nervous system has developed enough to make thought possible (Note 72). The second option is that a human fetus does survive the normal development of its nervous system, but despite that development, it never comes to be a person. No human fetus ever comes to be one of us. "You, the person, now share your space and your matter with a human animal, and it is the animal, not you, that started out as a fetus ... The animal is numerically different from you because it began to exist before you did, and because it has different dispositional properties from yours: you could not survive without psychological continuity, but the animal accompanying you manifestly can, or at least it could, and did, at one time" (Note 73).

On the strength of the tenor of these views, it seems therefore to be absurd in treating a newly formed embryo (fetus before mid-gestation or quickening) as a human being (Note 74). A fertilized cell counts as human, inasmuch as it contains a human genetic code, but it is not yet a person and so does not yet have the moral status of a full-fledged human person (Note 75). This runs along the line that an unformed mass of cells (fetus before mid-gestation or quickening) cannot count as a human being (Note 76).

\section{Discourse on the Term "Person"}

If we understand a person to be an individual who possess a degree of self-consciousness, then, the fetus (before mid-gestation or quickening) does not qualify to be called a person. Walters argues that the possession of self-consciousness is a necessary and sufficient condition to be a person of full moral status. The "term" person denotes an individual who possess self-consciousness and is thus entitled to moral standing (Note 77). Person is therefore a normative term that denotes an individual who possess maximal moral status. Only individuals who possess certain capacities of the higher brain can lay claim to the designation of person (Note 78). Being a person requires being able to function at a certain intellectual level.

Boethius defines a person, "As an individual substance of a rational nature" (Note 79). What is formed at conception does not give it the rights that we allocate to mature human beings. According to this notion fetuses are not human persons (Note 80).

In light of the abovementioned observations the term "person" stands to be regarded as uncongenial with the position of a fetus. A fetus fails to qualify as a person. A fetus slowly evolves toward personhood. As not all humans are fetuses, all fetuses are not persons or humans (Note 81).

\section{Practical Implication}

Ethicists and pro-life proponents would argue that the failure of affording to a fetus the status of "person" may serve as an affront to its right to life and its dignity as enshrined in for example section 11 of the Constitution of the Republic of South Africa, Act 108 of 1996. They would evoke section 11, which reads: "Everyone has the right to life," and forwarding sentiments uttered by the Constitutional Court whereby the rights to life and dignity were held as the "most important of all human rights." According to Judge Langa, (who can be categorized under the banner of pro-life movement), the Constitutional Court (case $S v$ Makwanyane) (Note 82), held that the state should be a role model of our society and must demonstrate society's own regard for human life and dignity by refusing to destroy life. If we follow the tenor of Thomas Aquinas's thought, we can put ourselves into his shoes, and argue that notwithstanding the sentiments in the Makwanyane-case, South Africa, for example, has turned a blind eye to this noble idea, by promulgating the Choice on Termination of Pregnancy Act (Act 92 of 1996). We are therefore faced with a dichotomy - the affording of the right to life and dignity as enshrined in the Constitution on the one hand and the Choice on Termination of Pregnancy Act on the other hand. It serves as a paragon for the notion that life is given with the one hand, just or only to be taken away again with the other hand. This indecision gives leverage for individual freedom and physical integrity as embedded in the the Choice on Termination of Pregnancy Act of South Africa. Similar laws are the United States Supreme Court decisions in Roe v Wade (Note 83) (successful privacy challenge of a law criminalizing abortion); Cruzan v Director Missouri Dept of Health (Note 84) (unsuccessful application to terminate feeding of patient in vegetative state, and Washington v Gluksberg (Note 85) (no constitutional basis for a right to assisted suicide). In the field of bioethics it has been argued that respect for the capacity of a fetus for human dignity prohibits gene 
selection techniques that entail abortion unless there is a countervailing rights-based reason for the abortion (Note 86).

In South Africa, the Choice on Termination of Pregnancy Act permits abortion on request by a woman during the first 12 weeks of her pregnancy, for medical and social reasons in the $13^{\text {th }}$ to the $20^{\text {th }}$ week of pregnancy and after the $20^{\text {th }}$ week, to save the life of the woman or to prevent the fetus being born malformed or injured. In Christian Lawyers' Association of South Africa v Minister of Health (Note 87) the Act was challenged in the High Court on the basis that it permitted the termination of human life. The High Court rejected the challenge on the basis that the word "everyone" used in section 11 to describe the bearers of the right to life, does not include a fetus.

\section{Conclusion}

Thomas Aquinas contents that if human life begins at conception, then abortion always involves the taking of human life. Thomas Aquinas denies therefore that human life begins at conception. He asserts that in the early stages of development of the embryo, namely the nutritive and sensory stages, a human being does not exist then. It is only in the final stage of development (the rational phase) of the embryo that we have a human soul and begins human life there. It is after the disintegration of the two former stages of development of the embryo. During the rational phase, it is then that the intellect needs a body. Until that capacity is present, the rational soul cannot be infused and hence can there be no human life. Thomas Aquinas answers the research question posed in this study, by exerts that human life cannot begin at conception, but at quickening. This comes around the twentieth week of pregnancy. Thomas Aquinas believes that the fetus or embryo becomes human at the moment of quickening and thus human life begins.

\section{References}

Augustine. Confessiones.

Aristotle. Met.

Aristotle. Phys. III.

Aristotle. De Gen.

Boethius. Contra Eutychen.

Choice on Termination of Pregnancy Act (Act 92 of 1996).

Christian Lawyers Association of South Africa v Minister of Health 1998 (4) SA 1113 (T).

Constitution of the Republic of South Africa, Act 108 of 1996.

Cruzan v Director Missouri Dept of Health 497 US 261 (1990).

Currie, I., \& de Waal, J. (2005). The Bill of Rights Handbook. In Association with Lawyers for Human Rights and the Law Society of South Africa. Fifth Edition. Juta \& Co. Ltd. Lansdowne, South Africa.

John, P. II. (1995). Evangelium Vitae: On the Value and Inviolability of Human Life. Washington, D.C.: United States Catholic Conference. Retrieved from http://www.nccbuscc.org/profile/tdocs

Kenny, A. (1993). Aquinas on Mind. Routledge. London.

Olsen, E. T. (1997). The Human Animal. Personal Identity without Psychology. Oxford University Press. Oxford.

Pasnau, R. (2002). Thomas Aquinas on Human Nature. A Philosophical Study of Summa Theologiae 1a 75-89. University of Colorado at Boulder. Cambridge University Press. Cambridge.

Sv Makwanyane 1995 (4) SA 391 (CC).

Schneiderman, L. J., \& Foreword (1997). In J. W. Walters, What is a Person? An Ethical Exploration. University of Illinois Press, Urbana and Chicago.

Roe v Wade 410 US 113 (1973).

Thomas Aquinas. Summa Theologiae.

Thomas Aquinas. In Met.

Thomas Aquinas. De Principiis.

Thomas Aquinas. In Quattuor libros Sententiarum.

Thomas Aquinas. Summa Contra Gentiles. 
Thomas Aquinas. In duodecim libros Metaphysicorum.

Thomas Aquinas. In librum primum De Generatione et corruption expositio.

Thomas Aquinas. Quaestiones disputatae de potentia.

Thomas Aquinas. Quaestiones disputatae de anima.

Thomas Aquinas. Quaestiones quodlibetalis.

Washington v Gluksberg 521 US 702 (1997).

Notes

Note 1. Olson (1997). 73.

Note 2. Lawrence J. Schneiderman. Foreword. In James W. Walters. 1997. What is a Person. An Ethical Exploration: ix.

Note 3. Walters (1997). 8.

Note 4. Walters (1997). 14.

Note 5. John Paul II (1995). Evangelium Vitae: On the Value and Inviolability of Human: ch. 3, sec 60. Available at http:///www.nccbuscc.org/profile/tdocs. In Pasnau (2002) 110.

Note 6. John Paul II (1995). ch. 1, sec 13.

Note 7. Pasnau (2002). 110.

Note 8. Pasnau, R. 2002. Thomas Aquinas on Human Nature. A Philosophical Study of Summa Theologiae 1a 75-89: 110. The Church, has officially, never taken a position on the philosophical question of when human life begins. In an encyclical, the late John Paul II noted that the Church has not "expressly committed itself" on the moment when human life begins. But the Church's rhetoric leaves little room for doubt. In that same encyclical, the Pope writes that abortion "destroys the life of a human being" and "directly violates the divine commandment "You shall not kill." That expresses the Church's position with regard to abortion.

Note 9. Robert Pasnau (2002). 101.

Note 10. Pasnau (2002). 418. Aquinas attributes the hidden-form theory to Anaxagoras (see II Sent 1.1.4 ad4; InMet VII.7.1439), presumably on the strength of various remarks in Aristotle (see Met. 1 3, 984a12-16, XI 6, 1063b25-30; Phys. III 4, 203a20-33; De gen. I 1, 314a8-30.

Note 11. Pasnau (2002). 101. InMet VII.7.1423.

Note 12. Pasnau (2002). 101. De Principiis 2.96-97 347.

Note 13. Pasnau (2002). 101-2. QDP 3.11 ad 11.

Note 14. Thomas Aquinas, Summa Theologiae 1a, q. 75, a. 5 ad 4.

Note 15. Pasnau (2002). 102. Thomas Aquinas, In quattuor libros Sententiarum II.18.2.3 ad 5. Anthony Kenny. 1993. Aquinas on Mind. Routledge, London: 138, 141.

Note 16. Thomas Aquinas, Summa Theologiae, 1a, q. 75, a. 5 ad 4.

Pasnau (2002). 102.

Note 17. Thomas Aquinas, Summa Theologiae 1a, q. 118, a. 1 ad 4. Pasnau (2002) 102.

Note 18. Thomas Aquinas, Summa Contra Gentiles II.89.1754.

Note 19. Thomas Aquinas, Summa Contra Gentiles II.89.1743.

Note 20. Pasnau (2002). 102.

Note 21. Pasnau (2002). 102.

Note 22. Pasnau (2002). 103.

Thomas Aquinas, In duodecim libros Metaphysicorum exposition VII.8.1456.

Note 23. Pasnau (2002). 121.

Note 24. Pasnau (2002). 121.

Note 25. Pasnau (2002). 121.

Note 26. Thomas Aquinas, In librum primum De generatione et corruptione expositio I.8.60. 
Note 27. Thomas Aquinas, In librum primum De generatione et corruptione expsotio i.8.60.

Note 28. Thomas Aquinas, Summa Theologiae, 1a, q. 76, a. 1.

Note 29. Thomas Aquinas, Quaestiones disputatae de potentia 3.9 ad 9.

Note 30. Pasnau (2002). 123.

Note 31. Thomas Aquinas, Quaestiones disputatae de potentia 3.9 ad 9.

Note 32. Thomas Aquinas, Summa Theologiae, 1a, q. 76, a. 3 obj 3.

Note 33. Thomas Aquinas, Summa Theologiae, 1a, q. 76, a. 4.

Note 34. Thomas Aquinas, Summa Theologiae, 1a, q. 76, a. 3 ad 3.

Note 35. Thomas Aquinas, Quaestiones disputatae de anima (Leonine vol. 24, 1).

Note 36. Thomas Aquinas, Summa Contra Gentiles II.89.1745.

Note 37. Thomas Aquinas, Summa Theologiae, 1a, q. 76, a. 3 ad 3.

Note 38. Pasnau (2002). 127.

Note 39. Pasnau (2002). 122.

Note 40. Thomas Aquinas, Summa Contra Gentiles II.89.1744.

Note 41. Thomas Aquinas, Summa Theologiae 1a, q. 118, a. 2 ad 2.

Note 42. Pasnau (2002). 124.

Note 43. Thomas Aquinas, Summa Theologiae 1a, q. 118, a. 2 ad 2.

Thomas Aquinas, Quaestiones quodlibetalis, 1.4.1.

Note 44. Pasnau (2002). 125.

Note 45. Thomas Aquinas, Summa Theologiae 1a, q. 76, a.5.

Note 46. Pasnau (2002). 114.

Note 47. Pasnau (2002). 114.

Note 48. Pasnau (2002). 115.

Note 49. Thomas Aquinas, Summa Contra Gentiles II.83-84.

Note 50. Augustine, Confessions I.vi.7.

Note 51. Thomas Aquinas, Quaestiones disputatae de potentia 3.10c.. Pasnau (2002) 117.

Note 52. Pasnau (2002). 118.

Note 53. Pasnau (2002). 119.

Note 54. Pasnau (2002). 106.

Note 55. Pasnau (2002). 106.

Note 56. Thomas Aquinas, Summa Theologiae 1a, q. 118, a. 2 ad 2. Pasnau (2002). 108.

Note 57. Pasnau (2002). 109.

Note 58. Pasnau (2002). 109.

Note 59. Pasnau (2002). 112.

Note 60. Thomas Aquinas, Summa Contra Gentiles II.89.1737.

Note 61. Pasnau (2002). 120.

Note 62. Olson (1997). 89-90.

Note 63. Olson (1997). 91.

Note 64. Olson (1997). 73.

Note 65. Olson (1997). 75.

Note 66. Pasnau (2002). 124.

Note 67. Olson (1997). 75. 
Note 68. Olson (1997). 77.

Note 69. Olson (1997). 77.

Note 70. Olson (1997). 79.

Note 71. Olson (1997). 79.

Note 72. Olson (1997). 79.

Note 73. Olson (1997). 80.

Note 74. Pasnau (2002). 106. The Supreme Court in Roe v Wade concluded that abortion does not take a human life. If the Court had taken the possibility that human life begins at conception, it never could have reasoned in the way it did.

Note 75. Pasnau (2002). 107.

Note 76. Pasnau (2002). 108.

Note 77. Walters (1997). 1-2.

Note 78. Walters (1997). 26.

Note 79. Boethius, Contra Eutychen, ch. 3.

Note 80. Pasnau (2002). 108.

Note 81. Walters (1997). 3.

Note 82. 1995 (3) SA 391 (CC).

Note 83. 410 US 113 (1973).

Note 84. 497 US 261 (1990).

Note 85. 521 US 702 (1997).

Note 86. Iain Currie \& Johan de Waal. 2005. The Bill of Rights Handbook : 288.

Note 87. 1998 (4) SA 1113 (T). 